\title{
The problems of dust extraction from air intake cyclonic dedusters of special vehicle engines
}

\begin{abstract}
An ejective system of dust extraction from a cyclonic deduster has been discussed. The influence of rate of extraction $m_{0}$ on the characteristics of purification efficiency and flow drag of cyclonic dedusters and individual cyclones has been presented. The values of optimum extraction rate have been given. The authors have analyzed the reasons for lower efficiency of multicyclone extraction versus the extraction of an individual cyclone, from which mutlicyclones are composed. A methodology of experimental research of extraction uniformity from individual cyclones of a multicyclone has been presented. Streams $Q_{S C}$ have been measured from individual cyclones of a multicyclone in the air cleaner. The authors have analyzed the performed investigations.
\end{abstract}

Key words: combustion engines, air filtration, multicyclone, deduster trap, rate of extraction, uniformity of extraction, purification efficiency

\section{Problemy odsysania pyłu z odpylaczy bezwładnościowych filtrów powietrza wlotowego silników pojazdów specjalnych}

\begin{abstract}
W artykule scharakteryzowano ejekcyjny system odsysania pylu z osadnika odpylacza bezwładnościowego. Przedstawiono wpływ stopnia odsysania $m_{0}$ na charakterystyki skuteczności i oporu przepływu odpylaczy bezwładnościowych i pojedynczych cyklonów. Podano wartości optymalnego stopnia odsysania. Przeanalizowano przyczyny mniejszej skuteczności odpylania multicyklonu niż pojedynczych cyklonów, z których jest on zbudowany. Opracowano metodykę badań eksperymentalnych równomierności odsysania pyłu z pojedynczych cyklonów multicyklonu. Pomierzono wartości strumieni odsysanych $Q_{S C} z$ pojedynczych cyklonów multicyklonu filtru powietrza. Przeprowadzono analizę wyników badań.
\end{abstract}

Słowa kluczowe: silniki spalinowe, filtracja powietrza, multicyklon, osadnik pyłu, stopień odsysania, równomierność odsysania, skuteczność odpylania

\section{Introduction}

For the filtration of intake air in modern combustion engines single stage air cleaners with a porous medium are used - most often it is a paper filter. Heavy duty vehicles, special vehicles including military vehicles (combat vehicles, armored vehicles, tanks) that are used under much more difficult conditions in terms of air dustiness than passenger vehicles are fitted with a two stage filtration system where the first stage is a monocyclone or a multicyclone (several identical cyclones of internal diameters not exceeding $\mathrm{D}=40 \mathrm{~mm}$ ) and the second stage is the porous medium.

The idea behind a two stage system is to initially separate higher mass dust in a cyclone deduster and leave the smaller dust particles for the second stage (most often paper filter) to clean them, which extends the maintenance periods until maximum flow drag $\Delta \mathrm{p}_{\text {fdop }}$ is exceeded.

The dust trapped by the cyclone is accumulated in the dust trap which has to be regularly emptied. In the obsolete air cleaner solutions this is done by the driver during maintenance periods. In the air cleaners of modern engines the dust removal from the traps is automatic through a self unsealing rubber cones and under conditions of high dustiness the phenomenon of ejective dust extraction with air stream $\mathrm{Q}_{\mathrm{S}}$ is used. The process of ejective dust extraction from a multicyclone is a complex and not fully explored process. It is thus purposeful to improve the organization of the dust

\section{Wprowadzenie}

Do filtracji powietrza wlotowego współczesnych silników samochodów osobowych stosuje się filtry jednostopniowe $\mathrm{z}$ przegrodą porowatą - najczęściej jest to wkład papierowy. Samochody ciężarowe, pojazdy specjalne, w tym pojazdy wojskowe (transportery, czołgi, bojowe wozy piechoty), które są eksploatowane w warunkach znacznie większego zapylenia powietrza niż samochody osobowe, wyposaża się w filtry z dwustopniowym systemem filtracji, gdzie pierwszym stopniem jest monocyklon lub multicyklon (kilkadziesiąt jednakowych ustawionych obok siebie cyklonów o średnicach wewnętrznych nieprzekraczających $\mathrm{D}=40 \mathrm{~mm}$ ), a drugim przegroda porowata.

Sensowność stosowania filtrów dwustopniowych polega na wstępnym odseparowaniu w odpylaczu bezwładnościowym ziaren pyłu o większej masie i „pozostawieniu” w strumieniu powietrza ziaren pyłu o mniejszych rozmiarach i masie oraz odfiltrowaniu w przegrodowym (najczęściej z wkładem papierowym) filtrze powietrza mniejszych ziaren, co wydłuża czas użytkowania systemu filtracji powietrza w silniku do osiągnięcia dopuszczalnej wartości oporu przepływu filtru powietrza $\Delta \mathrm{p}_{\text {fdop }}$.

Zatrzymany przez cyklony pył jest gromadzony we wspólnym dla wszystkich cyklonów osadniku pyłu, skąd należy go systematycznie usuwać. W starszych rozwiązaniach filtrów powietrza czynność tę wykonuje kierowca 
extraction system from the dust trap, which will result in a better efficiency, hence a lower mass of the dust incoming to the second stage of the filtration. As a result the maintenance period of the air cleaner system will extend.

\section{Basic characteristics of engine air cleaners}

The purpose of an air intake system in a combustion engine is to supply a sufficient amount of air of given parameters into the cylinders so that an appropriate fuel combustion process is ensured. The main components of the air intake system in a piston combustion engine are the air cleaner with its air intake, intake ducts, mass air flow meter, turbocharger, intercooler, manifold and the intake tracts in the engine head.

Air cleaners are generally characterized by the following: filtration efficiency, flow drag, filtration accuracy, absorbing capacity.

Filtration efficiency - the ratio of dust mass and mZF withheld by the filter to mass $m_{D F}$ supplied to the filter:

$$
\varphi_{\mathrm{f}}=\frac{\mathrm{m}_{\mathrm{ZF}}}{\mathrm{m}_{\mathrm{DF}}}
$$

In the case of a filter of more than one filtration stage $i$ the efficiency is then expressed as follows:

$$
\varphi_{\mathrm{f}}=1-\prod_{\mathrm{i}=1}^{\mathrm{n}}\left(1-\varphi_{\mathrm{fi}}\right)
$$

Flow drag - difference in pressures $\mathrm{p}_{1}$ before the filter and $\mathrm{p}_{2}$ past the filter:

$$
\Delta \mathrm{p}_{\mathrm{f}}=\mathrm{p}_{1}-\mathrm{p}_{2}
$$

For the filter of more than one filtration stage $\mathrm{i}$ the total flow drag is expressed as follows:

$$
\Delta \mathrm{p}_{\mathrm{f}}=\sum_{\mathrm{i}=1}^{\mathrm{n}} \Delta \mathrm{p}_{\mathrm{fi}}
$$

Filtration accuracy - maximum size of dust particle diameter $\mathrm{d}_{\mathrm{zmax}}$ in the air past the filter.

Capacity - mass of dust $\Delta \mathrm{m}$ withheld until the filter reaches its permissible flow drag $\Delta \mathrm{p}_{\text {fdop }}$.

\section{The problems with dust removal from the cyclonic deduster trap}

Under average operating conditions (after 20,000 km) along with air the engine sucks in approximately $60 \mathrm{~g}$ of dust. The engines of heavy duty and special vehicles are operated under conditions of much higher dustiness than it is in the case of passenger vehicles. A tank engine of a capacity of $\mathrm{V}_{\mathrm{S}}=38.8$ $\mathrm{dm}^{3}$ moving within an off road military training area with the speed of $\mathrm{v}=20 \mathrm{~km} / \mathrm{h}$ at the dust concentration $\mathrm{s}=1 \mathrm{~g} / \mathrm{m}^{3}$ sucks $170 \mathrm{~kg}$ of dust along with the air on a road portion of 1000 $\mathrm{km}$. The accumulation of such a huge amount of material in the trap is not recommended for the following reasons: podczas obsługiwania pojazdu. We współczesnych rozwiązaniach konstrukcyjnych filtrów powietrza usuwanie pyłu z osadników następuje samoczynnie poprzez rozszczelniające się gumowe stożki, a w warunkach dużego zapylenia wykorzystuje się zjawisko ejekcyjnego odsysania pyłu z osadnika strumieniem powietrza $\mathrm{Q}_{\mathrm{S}}$. Proces ejekcyjnego odsysania pyłu z multicyklonu jest problemem złożonym i do końca nierozpoznanym. Celowe są więc prace nad doskonaleniem organizacji systemu odsysania pyłu z osadnika multicyklonu, które spowodują wzrost skuteczności multicyklonu, a tym samym zmniejszenie masy pyłu napływającego wraz z powietrzem na drugi stopień filtracji. W efekcie, przy ograniczonej chłonności przegrody porowatej, wydłuży się czas użytkowania filtru.

\section{Podstawowe charakterystyki filtrów powietrza silników}

Zadaniem układu zasilania powietrzem silnika spalinowego jest dostarczenie do cylindrów silnika powietrza w odpowiednich ilościach i o odpowiednich parametrach w taki sposób, aby zapewnić prawidłowy przebieg procesu spalania paliwa. Głównymi elementami układu zasilania powietrzem tłokowego silnika spalinowego pojazdu mechanicznego są filtr powietrza wraz z czerpnią, przewody dolotowe, przepływomierz powietrza, sprężarka doładowująca, chłodnica powietrza, kolektor i kanały dolotowe w głowicy.

Filtry powietrza określają następujące powszechnie stosowane charakterystyki: skuteczność filtracji, opór przepływu, dokładność filtracji, chłonność filtru.

Skuteczność filtracji - iloraz masy pyłu $\mathrm{m}_{\mathrm{ZF}}$ zatrzymanego przez filtr i masy $\mathrm{m}_{\mathrm{DF}}$ dostarczonego do filtru - równanie (1). W przypadku filtru o kilku stopniach filtracji i skuteczność wyraża się zależnością (2).

Opór przepływu - różnica ciśnień $\mathrm{p}_{1}$ przed i $\mathrm{p}_{2}$ za filtrem równanie (3). Dla filtra o kilku stopniach filtracji i całkowity opór przepływu wyraża zależność (4).

Dokładność filtracji - maksymalny $\mathrm{d}_{\mathrm{zmax}}$ rozmiar ziarna pyłu w powietrzu za filtrem.

Chłonność - masa pyłu $\Delta$ m zatrzymanego do chwili osiągnięcia przez filtr określonej wartości oporu przepływu, najczęściej wartości oporu dopuszczalnego $\Delta \mathrm{p}_{\text {fdop }}$.

\section{Problemy usuwania pyłu z komory osadnika odpylacza bezwladnościowego}

W przeciętnych warunkach eksploatacji (po $20000 \mathrm{~km}$ przebiegu) wraz z powietrzem silnik samochodu osobowego zasysa około $60 \mathrm{~g}$ pyłu. Silniki samochodów ciężarowych i pojazdów specjalnych są eksploatowane w warunkach znacznie większego zapylenia powietrza niż samochody osobowe. Do silnika czołgu o pojemności skokowej $\mathrm{V}_{\mathrm{S}}=38,8 \mathrm{dm}^{3}$ jadącego z prędkością $\mathrm{V}=20 \mathrm{~km} / \mathrm{h}$ po drogach poligonowych przy stężeniu zapylenia $\mathrm{s}=1 \mathrm{~g} / \mathrm{m}^{3}$ dostaje się wraz z powietrzem wlotowym podczas $1000 \mathrm{~km}$ przebiegu ponad $170 \mathrm{~kg}$ pyłu. Magazynowanie w osadniku multicyklonu tak dużej masy pyłu nie jest wskazane ze względu na:

- konieczność stosowania osadnika o dużej pojemności, co zwiększa gabaryty filtru i utrudnia jego usytuowanie w pojeździe, 
- the trap size would have to be very big, which makes the filter size bigger thus making it difficult to fit into a vehicle,

- secondary dust intake occurs due to vibration on bumpy terrain,

- if the trap is full- dust entrainment and reduced cyclone efficiency occurs,

- unnecessary load with additional mass is exterted on the filter elements.

For these reasons under heavy dustiness conditions from the engine multicyclones the dust is removed on a continual basis through extraction. The effect of extraction is an increased efficiency in the multicyclone purification thus an extension in the maintenance periods before the maximum flow drag $\Delta \mathrm{p}_{\text {fdop }}$ is reached (Fig. 1).

Dust extraction takes place thanks to air stream $\mathrm{Q}_{\mathrm{S}}$, constituting a part of intake air (dusty air) $\mathrm{Q}_{0}$ into the cyclone (Fig. 2):

$$
\mathrm{Q}_{0}=\mathrm{Q}_{\mathrm{G}}+\mathrm{Q}_{\mathrm{S}}
$$

where: $Q_{G}-$ filter outlet air - engine intake.

Extraction stream $\mathrm{Q}_{\mathrm{S}}$ running through the trap lifts the dust and through the air tracts takes it outside of the vehicle.

In order to generate the extraction stream special fans or blowers are used. A disadvantage of this solution is the necessity to provide propulsion to the fans usually through an electric motor or seldom through a mechanical transmission from the engine crankshaft. The fan characteristics then heavily depend on the engine speed and consequently on the engine operating range. The location of the fan is also predetermined - near the engine - not necessarily an ideal spot for the deduster. Besides, the required continuity of operation of such a fan sets high requirements as to the durability of the drive system. Electric drive is a significant load on the energy generating systems. Electrically driven fan is used to extract dust from the trap fitted in the Leopard 2 tank [10]. Both described here devices put a significant load on the engine- they are additional power receivers. Because of that, in many air cleaner solutions in order to generate the extracting stream special ejectors using the energy of the

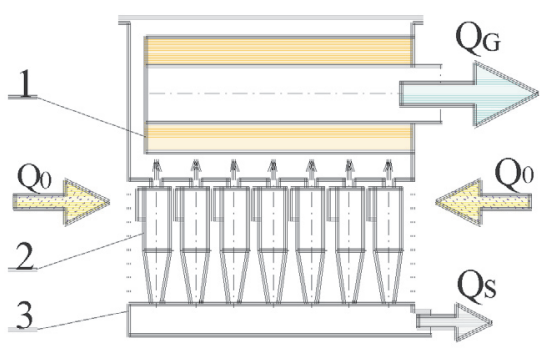

Air stream

purified in the filter

fed from the surroundings

$\Longrightarrow$ ejective extraction with the dust

Fig. 2. The principle of dust extraction from a multicyclone trap of a two stage air cleaner

Rys. 2. Zasada odsysania pylu z osadnika multicyklonu filtru dwustopniowego
- występowanie powtórnego zassania pyłu podczas wstrząsów pojazdu,

- całkowite zapełnienie osadnika - porywanie pyłu i spadek skuteczności cyklonów,

- niepotrzebne obciążenie konstrukcji filtru dodatkową masą.

Z tego względu w multicyklonach silników pojazdów eksploatowanych w warunkach dużego zapylenia powietrza stosuje się ciągłe usuwanie (przez odsysanie) z osadnika gromadzonego tam pyłu. Efektem stosowania odsysania jest podwyższenie skuteczności odpylania multicyklonu, a tym samym wydłużenie czasu pracy filtru powietrza do osiągnięcia dopuszczalnej wartości oporu przepływu $\Delta \mathrm{p}_{\text {fdop }}$ (rys. 1).

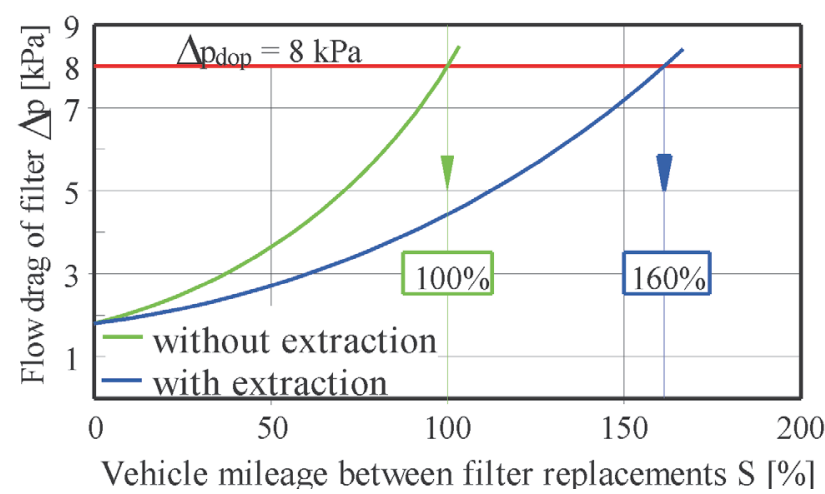

Fig. 1. Change in the flow drag - with and without an ejective dust extraction [11]

Rys. 1. Zmiana oporu filtru powietrza z ejekcyjnym usuwaniem pylu z osadnika i bez usuwania [11]

Odsysanie pyłu odbywa się dzięki wytworzeniu strumienia powietrza $Q_{S}$, stanowiącego część strumienia powietrza wlotowego (zanieczyszczonego) $\mathrm{Q}_{0}$ do multicyklonu (rys. 2) - równanie (5), gdzie: $\mathrm{Q}_{\mathrm{G}}$ - strumień powietrza wylotowego z filtru - wlotowego do silnika.

Strumień odsysania $\mathrm{Q}_{\mathrm{S}}$, przepływając przez komorę osadnika unosi przedostające się tam ziarna pyłu, a następnie odprowadzany jest przewodami na zewnątrz pojazdu.

Do wytwarzania strumienia odsysania stosuje się powszechnie specjalne wentylatory lub dmuchawy. Wadą tego rodzaju urządzeń jest konieczność ich napędzania, zwykle za pomocą silnika elektrycznego lub rzadziej przez przekładnię mechaniczną, od wału korbowego silnika. Charakterystyki wentylatora zależą wtedy silnie od prędkości obrotowej silnika, a w konsekwencji od zakresu pracy silnika. Z góry również zdeterminowane jest usytuowanie wentylatora przy silniku, w miejscu niekoniecznie dostosowanym do położenia odpylacza. Ponadto wymagana ciągłość działania wentylatora pociąga za sobą wysokie wymagania odnośnie do trwałości napędu. Napęd elektryczny wentylatora stanowi znaczące obciążenie układu wytwarzającego energię elektryczną na potrzeby pojazdu. Wentylator z napędem elektrycznym stosowany jest do odsysania pyłu z osadnika filtru powietrza czołgu Leopard 2 [10]. Oba opisane urządzenia obciążają energetycznie silnik - pobierają od niego 
flowing stream of compressed air $[1,11]$ or the energy of the exhaust stream $[6,7]$ are used.

The ejector is to force or intensify the extraction flow between two spaces constituting thermodynamic open spaces. The characteristic feature of an ejector is that it has two streams between which a transfer of momentum occurs. The stream called active has a higher value of the vector of momentum and its turn is accurately determined. The turn of the vector of the other stream (passive) is usually the same. Because of different ways of stream supply: active and passive there are different configurations of the ejectors (Fig. 3). The most rational method of forcing the extraction stream, however, is ejecting it to the stream of engine exhaust. moc. Z tego względu w rozwiązaniach wielu filtrów powietrza do wytworzenia strumienia odsysania jako urządzenie wymuszające przepływ stosuje się odpowiednie ejektory wykorzystujące energię strumienia sprężonego powietrza [1, 11] lub energię spalin wypływających z układu wylotowego silnika $[6,7]$.

Zadaniem ejektora jest wymuszenie lub zintensyfikowanie przepływu strumienia odsysania pomiędzy dwiema przestrzeniami, stanowiącymi zwykle termodynamiczne układy otwarte. Charakterystyczną cechą ejektora jest występowanie dwóch strumieni, pomiędzy którymi następuje wzajemne przekazywanie pędu. Strumień zwany aktywnym dysponuje większą wartością wektora pędu, a jego zwrot a)

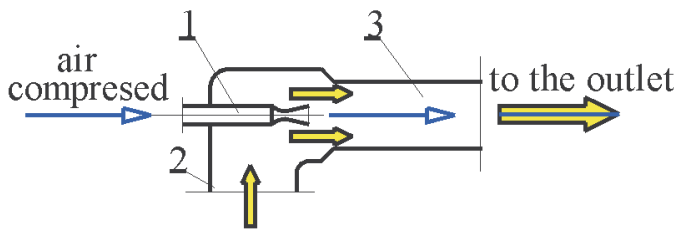

b)

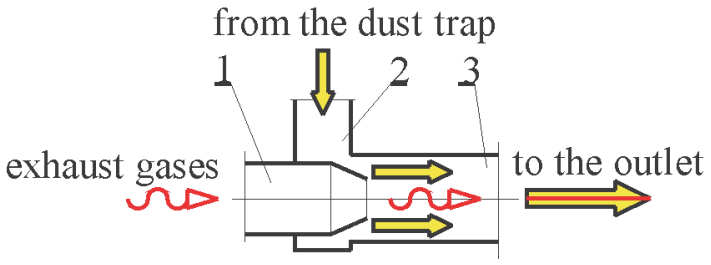

c)

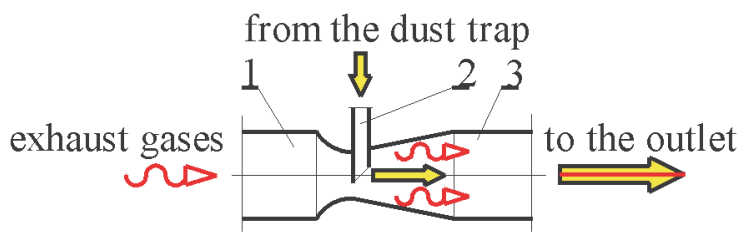

Fig. 3. The ejector configurations used in the extraction systems: a) compressed air, b and c) exhaust gases: 1 - intake tract of the active stream, 2 - intake tract of the passive stream, 3 - mixing chamber

Rys. 3. Stosowane konfiguracje ejektorów w układach odsysania do wymuszania strumienia ejekcyjnego: a) sprężonym powietrzem, b i c) spalinami: 1 - kanat dolotowy strumienia aktywnego, 2 - kanat dolotowy strumienia pasywnego, 3 - komora mieszania

The ejector configuration shown in Fig. $1 \mathrm{~b}$ is used in the ejection extraction systems from the dust traps of air cleaners in tanks: T-72 and PT-91 T-72 and PT-91 and in special vehicles built based on the platforms of these tanks as well as the BWP-1 combat vehicle.

The measure of the dust extraction intensity from the trap of a multicyclone (cyclone) is extraction rate $\mathrm{m}_{0}$ usually defined as a ratio of stream $Q_{S}$ in the extraction system to outlet stream from the multicyclone (cyclone) $\mathrm{Q}_{\mathrm{G}}$ i.e. engine intake $[2,3,7,9,12,13]$ :

$$
\mathrm{m}_{0}=\frac{\mathrm{Q}_{\mathrm{S}}}{\mathrm{Q}_{\mathrm{G}}} 100 \%
$$

The authors of several works on the influence of rate of extraction $\mathrm{m}_{0}$ on the purification efficiency concur that an increase in $\mathrm{m}_{0}$ results in a intense growth in purification efficiency $\varphi$, but only to a certain limit [1-5]. For the centrifugal inertia dedusters (Fig. 5) this value is 6-8\% (Fig. 4) [3] and for the multicyclone made by Pall Corporation 10\% [1]. A further growth in $\mathrm{m}_{0}$ does not cause any significant boost in the efficiency. jest ściśle określony. Zwrot wektora drugiego strumienia (pasywnego) jest zwykle taki sam. Ze względu na różne sposoby doprowadzania strumieni: aktywnego i pasywnego spotyka się różne konfiguracje ejektorów (rys. 3). Jednak najbardziej racjonalną metodą wymuszenia strumienia odsysania jest ejektowanie go do strumienia spalin wypływających z silnika.

Przedstawiona na rysunku $1 \mathrm{~b}$ konfiguracja ejektora jest zastosowana w układzie ejekcyjnego odsysania zanieczyszczeń z osadnika filtru powietrza czołgów T-72 i PT-91 T-72 i PT-91 i w pojazdach specjalnych zbudowanych na podwoziach tych czołgów oraz w bojowym wozie piechoty BWP-1.

Miarą intensywności odsysania pyłu z osadnika multicyklonu (cyklonu) jest stopień odsysania $\mathrm{m}_{0}$ definiowany zwykle jako stosunek wielkości strumienia $\mathrm{Q}_{\mathrm{S}} \mathrm{w}$ układzie odsysania do wielkości strumienia wylotowego z multicyklonu (cyklonu) $\mathrm{Q}_{\mathrm{G}}$ - wlotowego do silnika $[2,3,7,9,12$, 13] - równanie (6).

Autorzy nielicznych pracach poświęconych badaniom wpływu stopnia odsysania $m_{0}$ na efektywność odpylania są zgodni, że zwiększanie wartości $\mathrm{m}_{0}$ powoduje intensywny wzrost skuteczności odpylania $\varphi$, ale tylko do pewnej granicy 


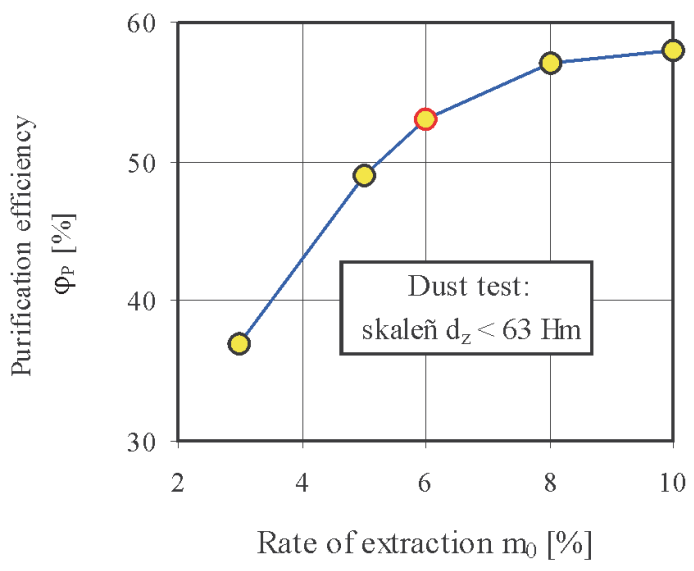

Fig. 4. The influence of extraction rate $m_{0}$ on the efficiency of the centrifugal inertia deduster

Rys. 4. Wplyw stopnia odsysania $m_{0}$ na skuteczność odpylania promieniowego odpylacza bezwładnościowego

A significant growth in the efficiency of axial cyclone deduster (Fig. 7) takes place when extraction rate $\mathrm{m}_{0}$ changes within $0-8 \%$ (Fig. 6). An increase in stream $Q_{S}$ causing the growth in the extraction rate above $\mathrm{m}_{0}=8 \%$ does not significantly improve the purification efficiency of the cyclone.

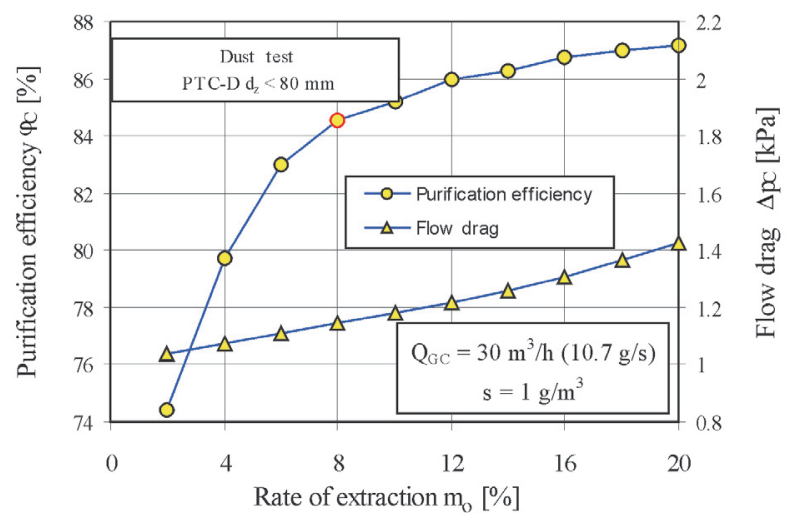

Fig. 6. The influence of extraction rate $m_{0}$ on the purification efficiency and flow drag of a flow-through axial cyclone [5]

Rys. 6. Wplyw stopnia odsysania pyłu $m_{0}$ na skuteczność odpylania

i opór przepływu cyklonu przelotowego z wlotem osiowym [5]

Dedusting from the dust trap in a tangent inlet returnable cyclone (Fig. 9) results in a shift of the purification efficiency characteristics $\varphi_{\mathrm{C}}=\mathrm{f}\left(\mathrm{Q}_{\mathrm{G}}\right)$ as rate of extraction $\mathrm{m}_{0}$ grows almost parallel towards higher values (Fig. 8). An increase in the flow drag of the tested cyclone being an inevitable phenomenon of the growth of extraction rate $\mathrm{m}_{0}$ is miniscule and results from the growth of inlet velocity $v_{0}$ according to the dependency $\Delta \mathrm{p}_{\mathrm{C}}=\mathrm{f}\left(\mathrm{v}_{0}^{2}\right)$.

The formation of extraction stream $\mathrm{Q}_{\mathrm{SC}}$ in the cyclone prevents intake stream $Q_{0 C}$ (external swirl) from returning to the cyclone outlet as a return stream (internal swirl) and forces it to go to the bottom of the conical part of the cyclone. In the bottom area of the conical section of the cyclone a ra-
[1-5]. Dla bezwładnościowego odpylacza promieniowego (rys. 5) jest to wartość 6-8\% (rys. 4) [3], a dla multicyklonu wykonanego przez Pall Corporation 10\% [1]. Dalszy wzrost $\mathrm{m}_{0}$ nie powoduje już istotnego wzrostu skuteczności.

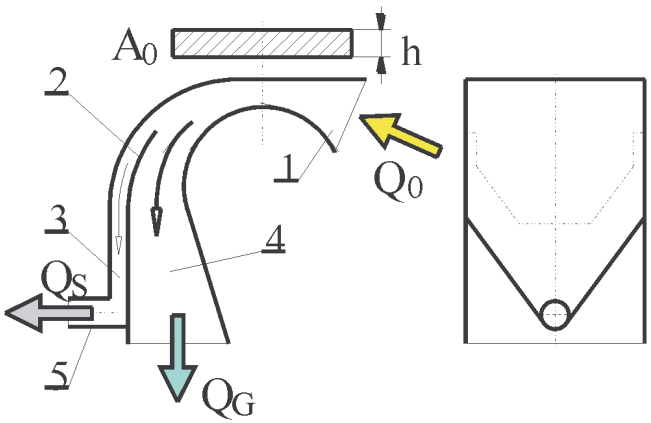

Air stream

$\Rightarrow$ contaminated with dust

$\Rightarrow$ purified in the filter

$\Rightarrow$ ejective extraction with the dust

Fig. 5. Schematics of centrifugal inertia deduster: 1 - dirty air intake,

2 - deduster, 3 - extraction channel, 4 - main channel, 5 - extraction pipe, $\mathrm{h}$ - height of the deduster channel [3]

Rys. 5. Schemat funkcjonalny promieniowego odpylacza bezwładnościowego: 1 - wlot powietrza zanieczyszczonego, 2 - separator, 3 - kanat odsysania, 4-kanat główny, 5 - rurka odsysająca, $h$-wysokość kanału odpylacza [3]

Istotny wzrost skuteczności odpylania cyklonu przelotowego z wlotem osiowym (rys. 7) następuje przy zmianie stopnia odsysania $\mathrm{m}_{0} \mathrm{w}$ zakresie $0-8 \%$ (rys. 6). Zwiększanie strumienia $\mathrm{Q}_{\mathrm{S}}$ powodującego wzrost stopnia odsysania powyżej wartości $\mathrm{m}_{0}=8 \%$ niewiele poprawia skuteczność odpylania cyklonu.

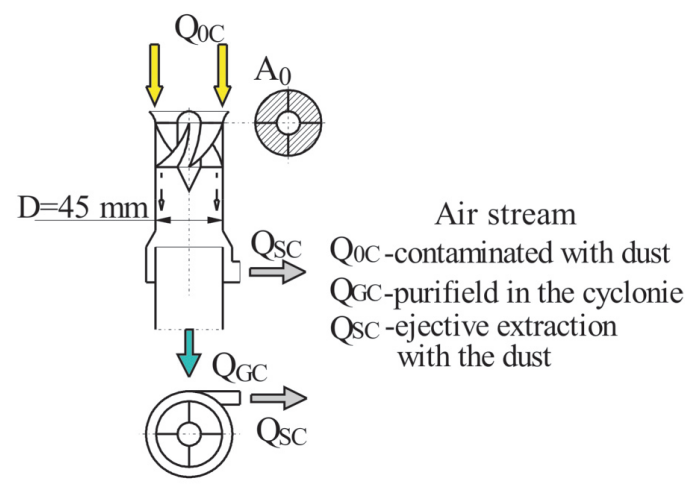

Fig. 7. Schematics of a flow-through axial cyclone

Rys. 7. Schemat funkcjonalny cyklonu przelotowego z wlotem osiowym

Odsysanie pyłu z osadnika cyklonu zwrotnego z wlotem stycznym (rys. 9) powoduje, że wraz ze wzrostem stopnia odsysania $\mathrm{m}_{0}$ następuje przesunięcie charakterystyk skuteczności odpylania $\varphi_{\mathrm{C}}=\mathrm{f}\left(\mathrm{Q}_{\mathrm{G}}\right)$ prawie równolegle w stronę wyższych wartości (rys. 8). Wzrost oporu przepływu badanego cyklonu będący nieodłącznym zjawiskiem zwiększania stopnia odsysania $\mathrm{m}_{0}$ jest nieznaczny i wynika ze wzrostu prędkości wlotowej $v_{0}$ zgodnie zależnością $\Delta \mathrm{p}_{\mathrm{C}}=\mathrm{f}\left(\mathrm{v}_{0}{ }^{2}\right)$. 
dial swirl forms from the wall towards the axis of the cyclone and then towards the intake to the dust trap. As a result some part of the air stream $\mathrm{Q}_{\mathrm{SC}}$ (Fig. 10b) separates and flows out of the conical section of the cyclone to the dust trap, dragging the separated dust particles of a larger size, which results in an increase in the purification efficiency.

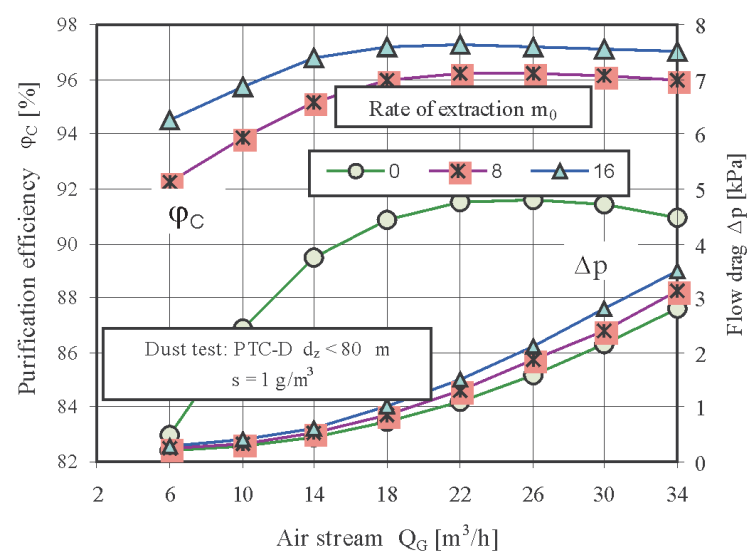

Fig. 8. The influence of extraction rate $\mathrm{m}_{0}$ on the characteristics of purification efficiency $\varphi_{\mathrm{C}}=\mathrm{f}\left(\mathrm{Q}_{\mathrm{G}}\right)$ and flow drag $\Delta \mathrm{p}_{\mathrm{C}}=\mathrm{f}\left(\mathrm{Q}_{\mathrm{G}}\right)$ of a tangent inlet returnable cyclone $\mathrm{D}-40$

Rys. 8. Wplyw stopnia odsysania pyłu m na charakterystyki skuteczności odpylania $\varphi_{C}=f\left(Q_{G}\right)$ i oporów przepływu $\Delta p_{C}=f\left(Q_{G}\right)$ cyklonu zwrotnego z wlotem stycznym $D-40$

An increase in the value of extraction stream $\mathrm{Q}_{\mathrm{SC}}$ (extraction rate $\mathrm{m}_{0}$ ) results in an arbitrary boundary between the two swirls getting farther from the outlet to the dust rap (Fig. 10) and the area covered by the extraction stream getting bigger. At the same time an increase in the axial velocity occurs in the area of the bottom of the conical section of the cyclone, which results in a growth of the velocity (towards the trap) of the dust particles in that zone. Hence, the number of the larger dust particles in the outlet stream and their size drops systematically [5] while the purification efficiency grows.

a)

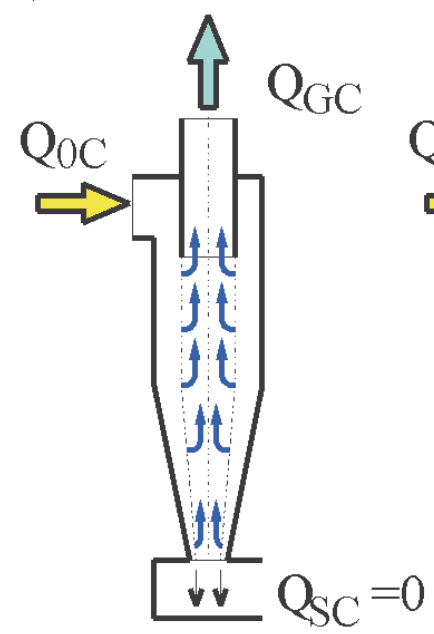

b)

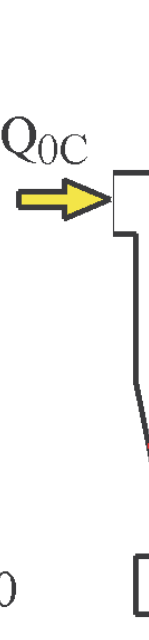

Wytworzenie w cyklonie strumienia odsysania $Q_{S C}$ powoduje, że strumień powietrza wlotowego $\mathrm{Q}_{0 \mathrm{C}}$, który ruchem śrubowym (wir zewnętrzny) przemieszcza się do dna części stożkowej cyklonu nie zawraca w całości w kierunku wylotu cyklonu jako strumień zwrotny - wir wewnętrzny. W obszarze dna części stożkowej cyklonu powstaje wir promieniowy od ściany do osi cyklonu, a następnie ku otworowi wlotowemu do osadnika. W efekcie pewna część strumienia powietrza o wartości $\mathrm{Q}_{\mathrm{SC}}$ (rys. 10b) oddziela się i wypływa ze strefy części stożkowej cyklonu otworem upustowym do osadnika pyłu, porywając ze sobą odseparowane ziarna pyłu większych rozmiarów, co powoduje wzrost skuteczności odpylania cyklonu.

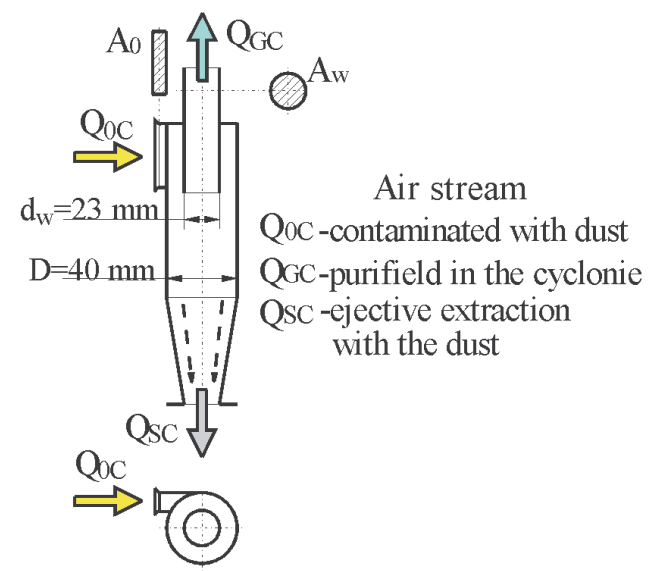

Fig. 9. Schematics of the tangent inlet returnable cyclone D-40 Rys. 9. Schemat funkcjonalny cyklonu zwrotnego z wlotem stycznym D-40

Wzrost wartości strumienia odsysania $\mathrm{Q}_{\mathrm{SC}}$ (stopnia odsysania $\mathrm{m}_{0}$ ) powoduje, że umowna granica rozdzielająca oba wiry znajduje się w coraz większej odległości od otworu upustowego (rys. 10), a obszar objęty strumieniem odsysania jest coraz większy. Jednocześnie następuje wzrost prędkości

Fig. 10. The flow of the air streams through the returnable tangent cyclone: a) without extraction, b, c) with extraction Rys. 10. Przeplyw strumieni powietrza przez cyklon zwrotny z wlotem stycznym: a) bez odsysania, b, c) z odsysaniem 
In the existing cyclone designs and mulitcyclone dedusters the optimum rate of extraction falls within the range of $\mathrm{m}_{0}=8 \ldots 15 \%[1,2,7,12,13]$.

From the analysis of the available design solutions of multicyclones and their extraction systems it results that if the dust trap range reaches many cyclones and the dust extraction takes place with one or two pipes then the following occurs $[1,3,5]$ :

- the extraction streams differ with different cyclones,

- mutual interaction of the swirl streams leaving the cyclones and entering the joint dust trap occurs,

- there is a possibility of return flows in cyclones located on the outer parts of a multicyclone.

In those cyclones of a multicyclone whose extraction rate $m_{0}$ is low, the resultant growth in the efficiency is miniscule. The cyclones, where the dedusting process occurs at extraction values $\mathrm{m}_{0}$ higher than the optimum values, do not achieve proportionally higher efficiencies. The number of cyclones in which the dedusting process occurs at the optimum extraction rate $m_{0}$ is low. This makes the parameters of the multicyclone much worse than the parameters of its individual cyclones if the same flow characteristics and the same extraction rate are maintained. This may be a cause of a lower multicyclone efficiency than it would result form the applied extraction rate for individual cyclones.

The characteristics shown in Fig. 11 prove that the efficiency of a multicyclone composed of 6 flow-through axial cyclones (Fig. 12) in comparison to an individual cyclone is $5-7 \%$ lower irrespective of the value of $\mathrm{m}_{0}[4]$.

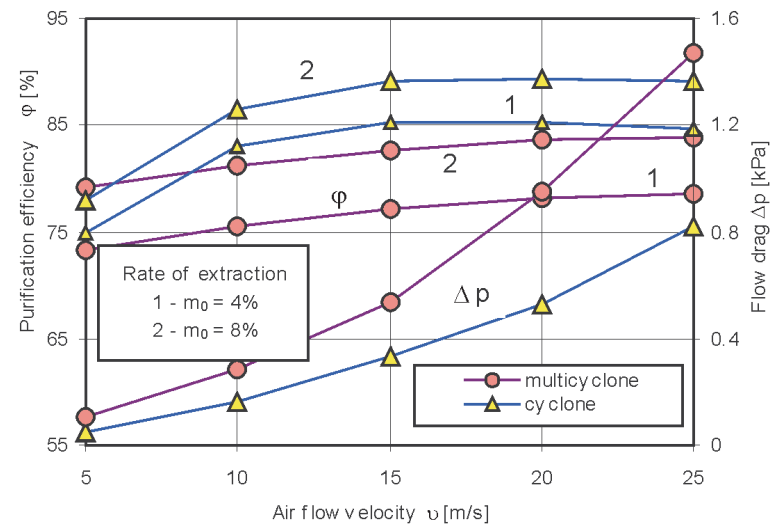

Fig. 11. Purification efficiency characteristics $\varphi=f\left(v_{0}\right)$ and flow drag characteristics $\Delta \mathrm{p}=\mathrm{f}\left(\mathrm{v}_{0}\right)$ of a flow-through axial cyclone and a multicyclone deduster for different ejective extraction rates $\mathrm{m}_{0}[4]$

Rys. 11. Charakterystyki skuteczności odpylania $\varphi=f\left(\mathrm{v}_{0}\right)$ oraz oporu przeplywu $\Delta p=f\left(\mathrm{v}_{0}\right)$ cyklonu przelotowego $z$ wlotem osiowym i odpylacza multicyklonowego dla różnych stopni ejekcyjnego odsysania $m_{0}[4]$

The purification efficiency of multicyclones depends not only on a proper selection of their flow parameters but also, to the same extent, on a uniform distribution of aerosol into all cyclones. Relevant available literature does not provide theoretical analyses and experimental investigations explaining this problem. osiowej strumienia w obszarze dna części stożkowej cyklonu, co skutkuje wzrostem prędkości (w kierunku osadnika) ziaren pyłu znajdujących się w tej strefie. Stąd udział liczbowy większych ziaren pyłu w strumieniu wylotowym oraz ich rozmiar systematycznie maleje [5], a skuteczność odpylania cyklonu ma coraz większą wartość.

W istniejących konstrukcjach cyklonów i odpylaczy multicyklonowych optymalny stopień odsysania zawiera się $\mathrm{w}$ przedziale $\mathrm{m}_{0}=8 \ldots 15 \%[1,2,7,12,13]$.

$\mathrm{Z}$ analizy dostępnych rozwiązań konstrukcyjnych multicyklonów i ich układów odsysania pyłu z osadnika wynika, że jeżeli osadnik pyłu obejmuje swym zasięgiem kilkadziesiąt cyklonów, a odsysanie pyłu z osadnika następuje dwoma lub jednym króćcem, to występuje wtedy $[1,3,5]$ :

- zróżnicowanie wartości strumieni odsysania z poszczególnych cyklonów,

- wzajemne oddziaływanie zawirowanych strumieni wypływających z cyklonów i wpływających do wspólnej komory osadnika pyłu,

- możliwość przepływów zwrotnych w cyklonach umiejscowionych na obrzeżu multicyklonu.

W tych cyklonach multicyklonu, w których stopień odsysania $\mathrm{m}_{0}$ ma małą wartość, wynikający stąd wzrost ich skuteczności jest nieznaczny. Z kolei cyklony, w których proces odpylania zachodzi przy znacznie większej wartości stopnia odsysania $\mathrm{m}_{0}$ niż wartość optymalna nie uzyskują proporcjonalnie większych wartości skuteczności odpylania. Liczba cyklonów, w których proces odpylania zachodzi przy optymalnej wartości stopnia odsysania $\mathrm{m}_{0}$ jest niewielka. To powoduje, że parametry pracy multicyklonu, przy zachowaniu średnio tych samych cech przepływu i tej samej wartości stopnia odsysania, bywają znacznie gorsze od parametrów pracy pojedynczych cyklonów, z których jest on zbudowany. Może to być przyczyną mniejszej skuteczności odpylania multicyklonu, niż wynikałoby to z zastosowanego stopnia odsysania dla pojedynczych cyklonów.

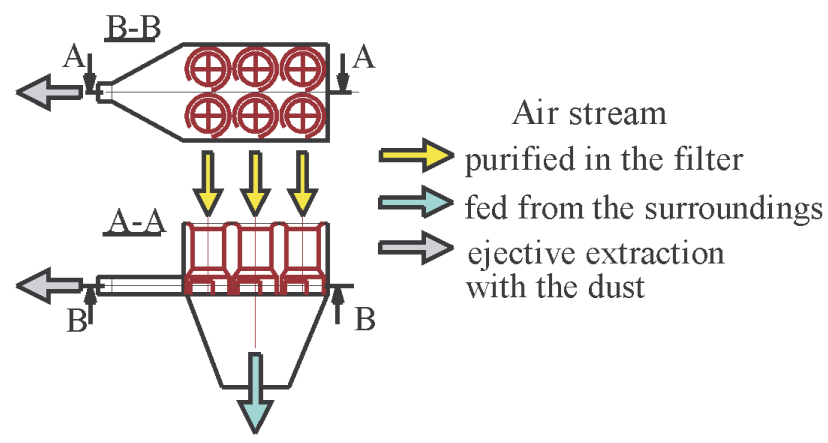

Fig. 12. Schematics of a multicyclone deduster of flow-through cyclones Rys. 12. Schemat funkcjonalny odpylacza multicyklonowego cyklonów przelotowych

Przedstawione na rysunku 11 charakterystyki dowodzą, że skuteczność odpylania multicyklonu zbudowanego $\mathrm{z}$ 6 cyklonów przelotowych z wlotem osiowym (rys. 12) w odniesieniu do pojedynczego cyklonu jest o 5-7\% mniejsza niezależnie od stopnia $\mathrm{m}_{0}[4]$. 


\section{Experimental investigations on dedusting from individual cyclones}

\subsection{Methodology and scope of research}

The investigations aimed at a determination of the influence of the multicyclone design and its dust trap on the values of streams $\mathrm{Q}_{\mathrm{SC}}$ extracted from individual cyclones of a multicyclone of a special vehicle (T-72 tank Fig. 13) under a working name of T2 whose design has been shown in Figure 14 . The T2 multicyclone is made of 96 vertically set returnable tangent cyclones of internal diameter $\mathrm{D}=40 \mathrm{~mm}$.

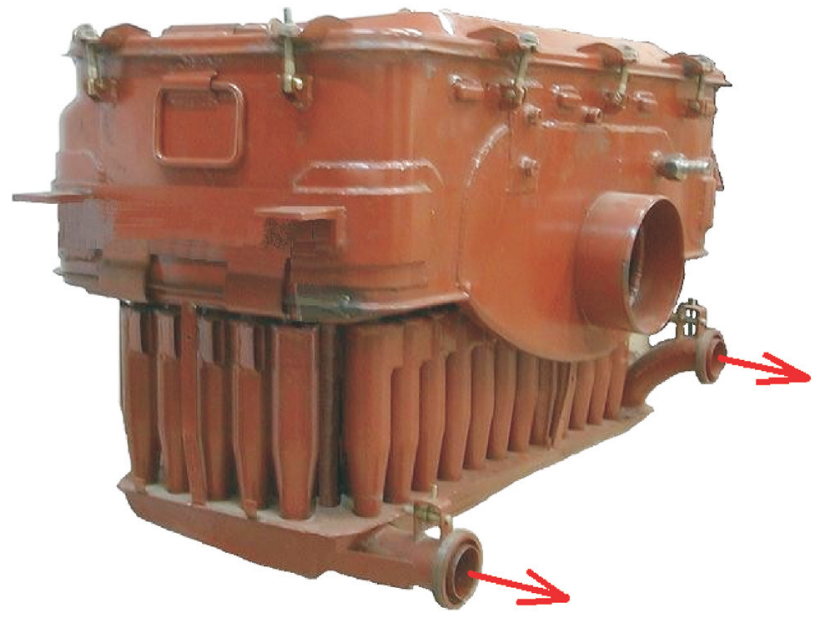

Fig. 13. Air cleaner of a special vehicleT-72 Rys. 13. Filtr powietrza pojazdu specjalnego T-72

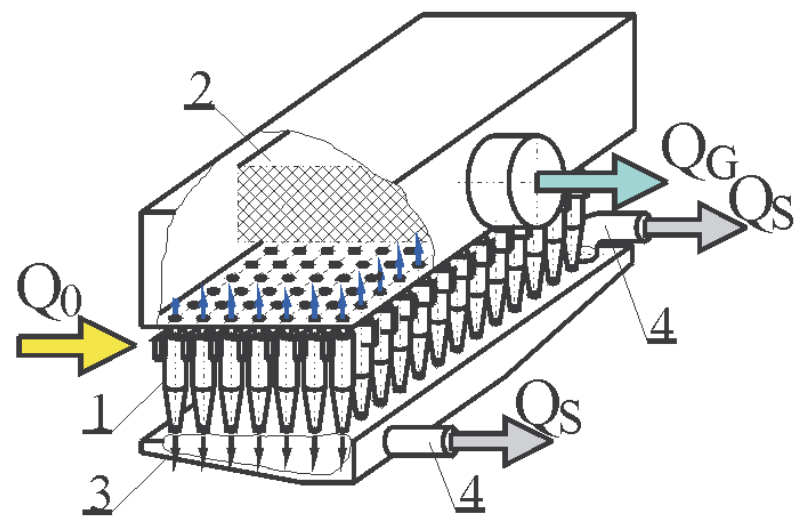

Skuteczność odpylania multicyklonów zależy więc nie tylko od właściwego doboru ich parametrów konstrukcyjnych i przepływowych, ale w równym stopniu od równomiernego rozdziału aerozolu na wszystkie cyklony. W dostępnej literaturze brak jest analiz teoretycznych i badań eksperymentalnych wyjaśniających ten problem.

\section{Badania eksperymentalne równomierności odsysania pyłu z pojedynczych cyklonów}

\subsection{Zakres i metodyka badań}

Badania miały na celu określenie wpływu konstrukcji multicyklonu i jego osadnika pyłu na wartości strumieni odsysanych $\mathrm{Q}_{\mathrm{SC}} \mathrm{z}$ pojedynczych cyklonów multicyklonu filtru powietrza pojazdu specjalnego (czołgu T-72 - rys. 13) o roboczej nazwie T2, którego konstrukcję przedstawiono na rysunku 14. Multicyklon T2 zbudowany jest z 96. pionowo ustawionych cyklonów zwrotnych z wlotem stycznym o średnicy wewnętrznej $\mathrm{D}=40 \mathrm{~mm}$.

Odsysanie pyłu z osadnika multicyklonu, będącego pustą wewnątrz komorą o kształcie zbliżonym do płaskiego prostopadłościanu, realizowane jest punktowo dwoma króćcami odsysania (rys. 14). Rozmieszczenie cyklonów w różnej odległości od otworów wylotowych króćców odsysania ma niewątpliwie wpływ na relację między strumieniami odsysania i wylotowym w poszczególnych cyklonach.

Zakres badań obejmował określenie wartości strumieni odsysanych $\mathrm{Q}_{\mathrm{SC}} \mathrm{z}$ pojedynczych skrajnych cyklonów multicyklonu filtru powietrza. Nie jest możliwe określenie

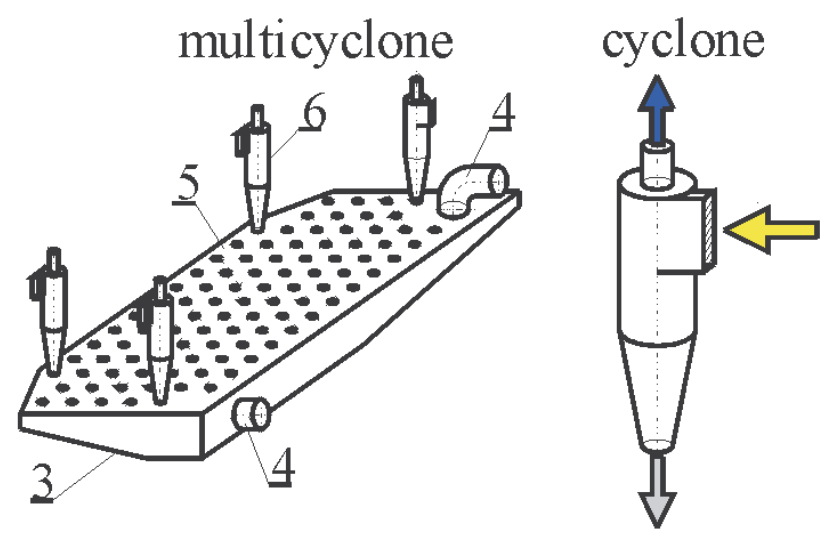

Fig. 14. Schematics of an air cleaner of a T-72 special vehicle: 1 - multicyclone T2, 2 - porous partition, 3 - trap, 4 - extraction tracts, 5 - cyclone fixing plate, 6 - cyclones

Rys. 14. Schemat konstrukcyjny filtru powietrza pojazdu specjalnego T-72: 1 - multicyklon T2, 2 - przegroda porowata, 3 - osadnik, 4 - króćce odsysania, 5 - ptyta mocujaca cyklony, 6-cyklony

The dust extraction from the multicyclone dust trap which is a hollow chamber of a shape similar to a flat cubicoid is realized through two extracting pipes (Fig. 14). The placement of the cyclones at different distances from the outlets of the extraction pipes has a definite impact on the relation between the extraction and outlet streams in individual cyclones.

The scope of the investigations covered the determination of the values of streams $\mathrm{Q}_{\mathrm{SC}}$ of individual peripheral cyclones wartości strumieni $\mathrm{Q}_{\mathrm{SC}} \mathrm{z}$ cyklonów znajdujących się $\mathrm{w}$ środkowej części muticyklonu zaproponowaną metodą. Badania wykonano w warunkach, gdy przez osadnik multicyklonu przepływa kolejno strumień odsysania $Q_{S}$ o wartościach wynikających ze stopni odsysania $\mathrm{m}_{0}=4$, 8 i $16 \%$ i nominalnego zapotrzebowania powietrza przez silnik $Q_{\mathrm{Sil}}=\mathrm{Q}_{\mathrm{G}}=3400 \mathrm{~m}^{3} / \mathrm{h}(1,22 \mathrm{~kg} / \mathrm{s})$. 
of a multicyclone in an air cleaner. It is not possible to determine the value of stream $\mathrm{Q}_{\mathrm{SC}}$ from the cyclones located in the mid part of the multicyclone with the proposed method. The tests were performed under conditions of the dust trap flow-through of stream $\mathrm{Q}_{\mathrm{S}}$ of values resulting from extraction rates $\mathrm{m}_{0}=4,8$ and $16 \%$ respectively and a nominal air demand by the engine $\mathrm{Q}_{\mathrm{Sil}}=\mathrm{Q}_{\mathrm{G}}=3400 \mathrm{~m}^{3} / \mathrm{h}(1.22 \mathrm{~kg} / \mathrm{s})$.

The values of extraction streams $\mathrm{Q}_{\mathrm{S}}$ from the multicyclone dust trap for the rates of extraction assumed for the tests $\left(\mathrm{m}_{0}=4,8\right.$ and $\left.16 \%\right)$ were calculated from the dependence:

$$
\mathrm{Q}_{\mathrm{S}}=\mathrm{m}_{0} \mathrm{Q}_{\mathrm{G}}
$$

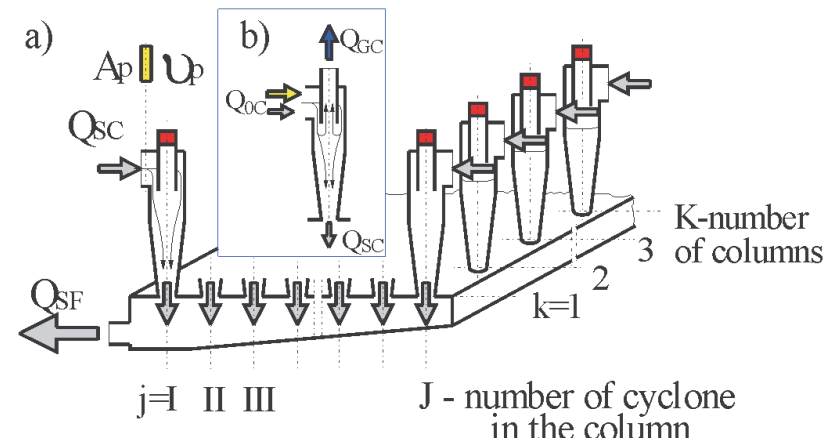

Fig. 15. The flow of stream $\mathrm{Q}_{\mathrm{SC}}$ in the cyclone: a) in operation, b) in measurement phase. I, II, II,...j....J - consecutive number of cyclone in the column - numbers of rows; $1,2,3, \ldots \mathrm{k} . . \mathrm{K}$ - consecutive number of cyclone in the row- number of columns

Rys. 15. Przeptyw strumienia $Q_{S C}$ w cyklonie: a) podczas pracy, b) w czasie pomiaru. I, II, II,...j...J-numer kolejny cyklonu w kolumnie - liczba rzędów; 1, 2, 3,...k...K-numer kolejny cyklonu w rzędzieliczba kolumn

The value of streams $\mathrm{Q}_{\mathrm{SC}}$ extracted from individual cyclones of a multicyclone in an air cleaner were determined through an indirect method consisting in measuring of the values of the intake stream $\mathrm{Q}_{0 \mathrm{C}}$ into the cyclone, which assumes the value of $\mathrm{Q}_{0 \mathrm{C}}=\mathrm{Q}_{\mathrm{SC}}$ if outlet stream $\mathrm{Q}_{\mathrm{GC}}=0$ from the cyclone. Such an incidence will take place if the outlets from all the cyclones of a multicyclone are closed and from dust trap stream $Q_{S}$ is extracted being the sum of $Q_{S C}$ from the individual cyclones - Fig. 15:

$$
\mathrm{Q}_{\mathrm{S}}=\sum_{\mathrm{j}=\mathrm{I}}^{\mathrm{J}} \sum_{\mathrm{k}=1}^{\mathrm{K}} \mathrm{Q}_{\mathrm{SC}_{\mathrm{jk}}}
$$

The value of streams $\mathrm{Q}_{\mathrm{SC}}$ from individual cyclones was determined on a special stand (Fig. 16) through an indirect method consisting in measuring the flow velocity in the outlet of a cyclone with a fan meter (Testo 400) in a cross section of known area $A_{p}$ using the dependence:

$$
\mathrm{Q}_{\mathrm{SCjk}}=\mathrm{v}_{\mathrm{pjk}} \cdot \mathrm{A}_{\mathrm{p}}
$$

\subsection{Test results analysis}

Streams $\mathrm{Q}_{\mathrm{SC}}$ extracted from individual cyclones of a multicyclone assume very different values (Fig. 17-20).
Wartości strumieni odsysania $\mathrm{Q}_{\mathrm{S}} \mathrm{z}$ osadnika multicyklonu dla przyjętych do badań stopni odsysania $\left(\mathrm{m}_{0}=4,8 \mathrm{i} 16 \%\right)$ obliczono z zależności (7).

Wartości strumieni odsysanych $\mathrm{Q}_{\mathrm{SC}} \mathrm{z}$ pojedynczych cyklonów multicyklonu filtru powietrza określono metodą pośrednią polegającą na pomierzeniu wartości strumienia wlotowego $\mathrm{Q}_{0 \mathrm{C}}$ do cyklonu, który dla przypadku, gdy strumień wylotowy z cyklonu $\mathrm{Q}_{\mathrm{GC}}=0$ przyjmuje wartość $\mathrm{Q}_{\mathrm{OC}}=\mathrm{Q}_{\mathrm{SC}}$. Przypadek taki zaistnieje wtedy, kiedy otwory wylotowe z wszystkich cyklonów multicyklonu będą zasłonięte, a z osadnika pyłu multicyklonu odsysany jest strumień $\mathrm{Q}_{\mathrm{S}}$ będący sumą strumieni odsysanych $\mathrm{Q}_{\mathrm{SC}} \mathrm{z}$ pojedynczych cyklonów - rys. 15 - równanie (8).
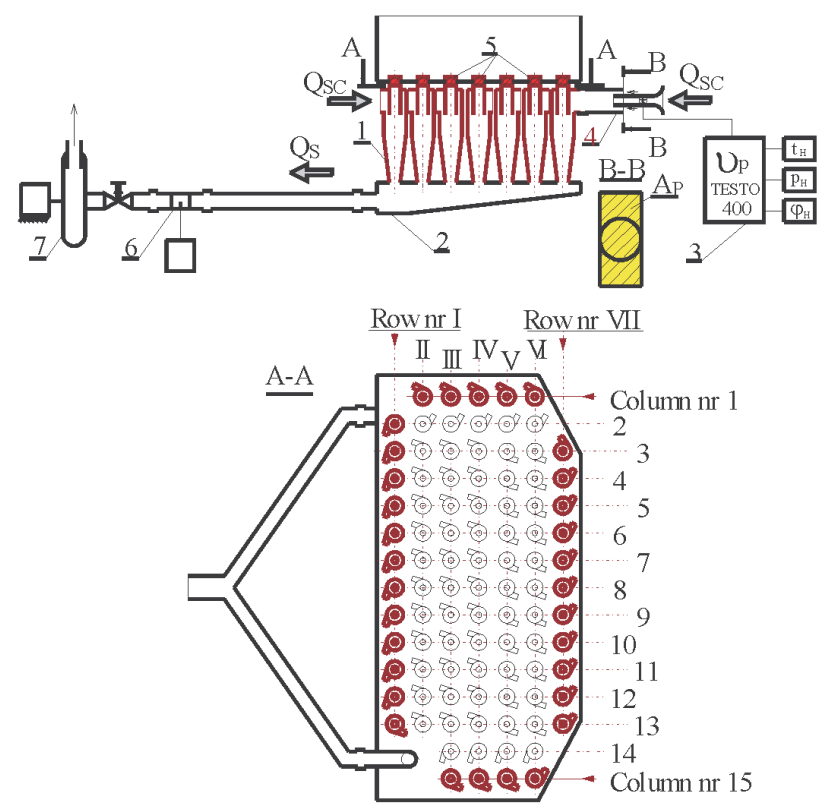

Fig. 16. A stand for the measurement of the values of the streams extracted from individual cyclones of a T2 multicyclone: 1 - multicyclone,

2 - dust trap, 3 - TESTO - 400 device, 4 - measurement channel, 5 - plugs closing the flow, 6 - flow meter, 7 - suction fan

Rys. 16. Stanowisko do pomiaru wartości strumieni odsysanych z pojedynczych cyklonów multicyklonu T2: 1 - multicyklon, 2-osadnik pytu, 3-przyrzad TESTO-400, 4-kanat pomiarowy, 5-korki zamykajace przeplyw, 6-przeplywomierz, 7-wentylator ssawny

Wartości strumieni $\mathrm{Q}_{\mathrm{SC}} \mathrm{z}$ pojedynczych cyklonów określano na specjalnym stanowisku (rys. 16) metodą pośrednią polegającą na pomiarze sondą wiatraczkową przyrządu Testo 400 prędkości przepływu powietrza w króćcu wlotowym cyklonu w przekroju poprzecznym o znanym polu powierzchni $\mathrm{A}_{\mathrm{p}}$, stosując zależność (9).

\subsection{Analiza wyników badań}

Strumienie odsysane $Q_{S C}$ z pojedynczych cyklonów multicyklonu przyjmują bardzo zróżnicowane wartości (rys. 17-20). Niezależnie od wartości strumienia odsysania $\mathrm{Q}_{\mathrm{SF}}$, dla cyklonów, których wylot strumieni odsysania znajduje się blisko króćców odsysania z osadnika multicyklonu, wartości $\mathrm{Q}_{\mathrm{SC}}$ są największe i zawierają się w zakresie $\mathrm{Q}_{\mathrm{SC}}=2,5-5,95$ $\mathrm{m}^{3} / \mathrm{h}(0,89-2,13 \mathrm{~g} / \mathrm{s})$ - rys. 17 . Strumienie $\mathrm{Q}_{\mathrm{SC}}$ odsysane $\mathrm{z}$ 
Irrespective of the value of extraction stream $\mathrm{Q}_{\mathrm{SF}}$, for the cyclones whose intake is located very close to the trap extraction pipes, values $\mathrm{Q}_{\mathrm{SC}}$ are the highest and fall within $\mathrm{Q}_{\mathrm{SC}}=2.5-5.95 \mathrm{~m}^{3} / \mathrm{h}(0.89-2.13 \mathrm{~g} / \mathrm{s})-$ Fig. 17. Streams $\mathrm{Q}_{\mathrm{SC}}$ extracted from the mid cyclones of an investigated row located a little farther from the trap extraction pipes assume values within the range of $\mathrm{Q}_{\mathrm{SC}}=1.05-2.95 \mathrm{~m}^{3} / \mathrm{h}(0.38-1.06$ $\mathrm{g} / \mathrm{s}$ ), hence they are more than $50 \%$ lower.

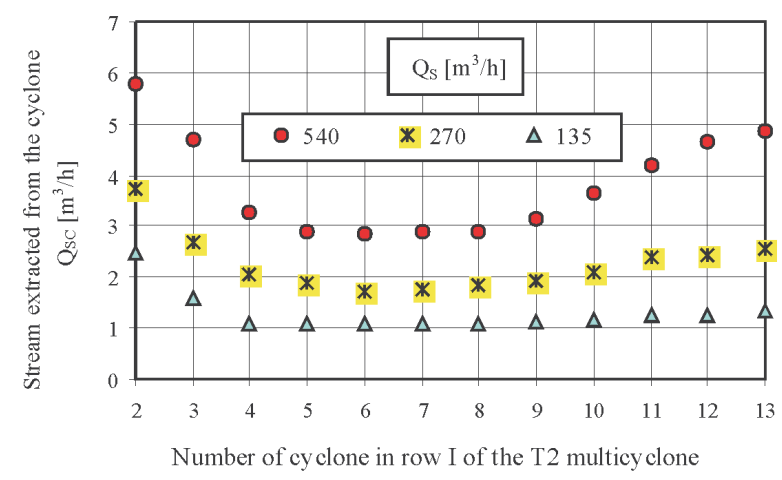

Fig. 17. The values of streams $\mathrm{Q}_{\mathrm{SC}}$ extracted from individual cyclones of the first row of a T2 multicyclone

Rys. 17. Wartości strumieni odsysanych $Q_{S C}$ z pojedynczych cyklonów I rzędu multicyklonu T2

As the locations of the cyclones get farther from the front of the dust trap (extraction pipes) towards the rear part of the multicyclone, a systematic drop in the value of streams $\mathrm{Q}_{\mathrm{SC}}$ (Fig. 18 and 19) occurs.

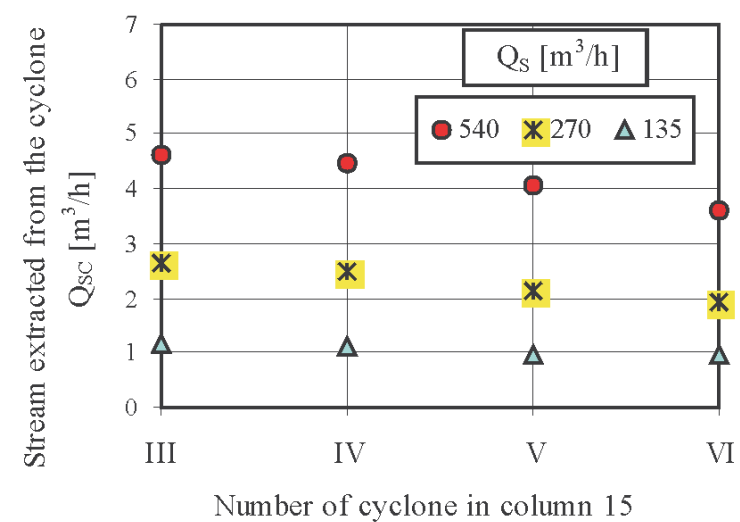

Fig. 19. The values of streams $\mathrm{Q}_{\mathrm{SC}}$ extracted from the cyclones of column 15 of the T2 multicyclone

Rys. 19. Wartości strumieni odsysanych $Q_{S C}$ z cyklonów kolumny nr 15 multicyklonu T2

In the last (VII) row, the stream extracted from the individual cyclones assume values that are half lower (Fig. 20) than it is in the first multicyclone row (I). Lower are also the differences between the maximum and minimum values of streams $Q_{\mathrm{SC}}$ and for $\mathrm{Q}_{\mathrm{S}}=540 \mathrm{~m}^{3} / \mathrm{h}(193 \mathrm{~g} / \mathrm{s}), 270 \mathrm{~m}^{3} / \mathrm{h}(96.7$ $\mathrm{g} / \mathrm{s}), 135 \mathrm{~m}^{3} / \mathrm{h}(48.4 \mathrm{~g} / \mathrm{s})$ they assume the values 11,14 and $16 \%$ respectively. cyklonów środkowych badanego rzędu, a znajdujących się w pewnym oddaleniu od króćców odsysania, przyjmują wartości w granicach $\mathrm{Q}_{\mathrm{SC}}=1,05-2,95 \mathrm{~m}^{3} / \mathrm{h}(0,38-1,06$ $\mathrm{g} / \mathrm{s}$ ), a więc są o ponad $50 \%$ mniejsze.

Wraz z oddalaniem się położenia cyklonów od czoła osadnika pyłu (od króćców odsysania) ku tylnej ścianie multicyklonu, następuje systematyczny spadek wartości strumieni odsysanych $\mathrm{Q}_{\mathrm{SC}}$ (rys. 18 i 19).

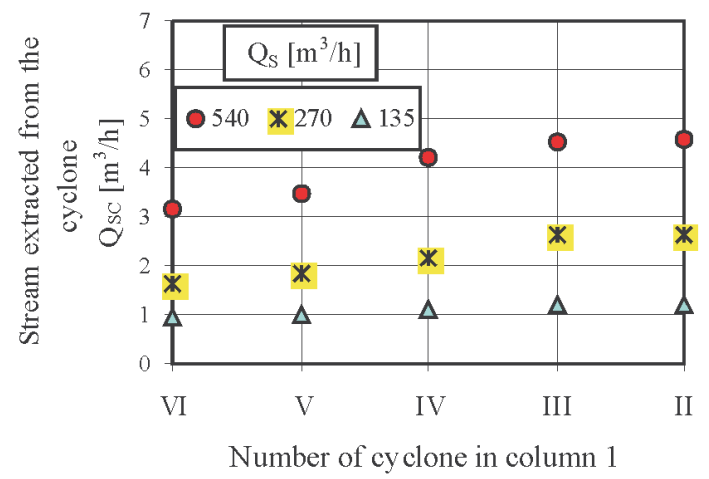

Fig. 18. The values of streams $\mathrm{Q}_{\mathrm{SC}}$ extracted from the cyclones of column 1 of the T2 multicyclone

Rys. 18. Wartości strumieni odsysanych $Q_{S C}$ z cyklonów kolumny nr 1 multicyklonu $T 2$

W ostatnim (VII) rzędzie cyklonów strumienie odsysane z pojedynczych cyklonów przyjmują wartości o połowę mniejsze (rys. 20) niż w rzędzie pierwszym (I) multicyklonu. Mniejsze są też różnice między maksymalnymi a minimalnymi wartościami strumieni odsysanych $\mathrm{Q}_{\mathrm{SC}}$ i dla $\mathrm{Q}_{\mathrm{S}}=540$ $\mathrm{m}^{3} / \mathrm{h}(193 \mathrm{~g} / \mathrm{s}), 270 \mathrm{~m}^{3} / \mathrm{h}(96,7 \mathrm{~g} / \mathrm{s}), 135 \mathrm{~m}^{3} / \mathrm{h}(48,4 \mathrm{~g} / \mathrm{s})$ przyjmują odpowiednio wartości 11, 14 i 16\%.

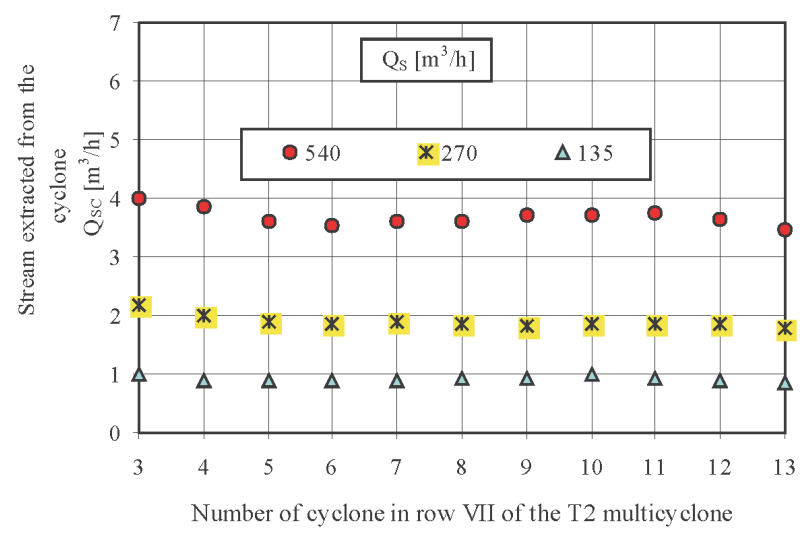

Fig. 20. The values of streams $\mathrm{Q}_{\mathrm{SC}}$ extracted from the cyclones of row VII of the T2 multicyclone

Rys. 20. Wartości strumieni odsysanych $Q_{S C}$ z cyklonów VII rzędu multicyklonu $T 2$

\section{Podsumowanie}

W multicyklonie zbudowanym z dużej liczby (100 sztuk i więcej) cyklonów mających wspólny osadnik pyłu, zastosowanie tylko dwóch króćców odsysających pył z osadnika powoduje, że odległości otworów wylotowych strumieni 


\section{Conclusions}

In a multicyclone composed of a high number of cyclones $(100+)$ having a joint dust trap, the application of only two extracting pipes makes the distance of the outlets of the streams extracted from individual cyclones different, which naturally generates a difference between the streams extracted from the individual cyclones and may have a negative effect on the purification efficiency of those individual cyclones as well as the whole multicyclone.

The highest values of streams $Q_{\mathrm{SC}}$ occur for cyclones located the closest to the dust extraction pipe. As the location of the individual cyclones gets farther from the dust extraction pipe the values of streams $\mathrm{Q}_{\mathrm{SC}}$ systematically drop and for the farthest cyclones assume values that are lower by $35-50 \%$.

The developed investigation methodology of measuring stream $\mathrm{Q}_{\mathrm{SC}}$ from individual cyclones of a multicyclone in an air cleaner at the same time being an original author's work can be used to measure the lack of uniformity of extraction from dust traps of multicyclones of similar design having not only cubicoidal but also circular chambers.

Ensuring a uniformity of dust extraction from the individual cyclones is another stage in the improvement of the air extraction system from a dust trap of a mutlicyclone. odsysanych poszczególnych cyklonów od króćca układu odsysającego są niejednakowe, co stwarza w naturalny sposób różnice między wartościami strumieni odsysanych z pojedynczych cyklonów i może mieć negatywny wpływ na skuteczność odpylania pojedynczych cyklonów i multicyklonu.

Największe wartości strumieni odsysanych $\mathrm{Q}_{\mathrm{SC}}$ występują dla cyklonów znajdujących się najbliżej króćca odsysania pyłu z osadnika. Wraz z oddalaniem się położenia kolejnych cyklonów od króćca odsysania wartości strumieni odsysanych $\mathrm{Q}_{\mathrm{SC}}$ systematycznie maleją i dla cyklonów będących najdalej przyjmują wartości o 35-50\% mniejsze.

Opracowana metodyka pomiarów strumieni $\mathrm{Q}_{\mathrm{SC}} \mathrm{z}$ pojedynczych cyklonów multicyklonu filtru powietrza, będąca oryginalnym opracowaniem autora, może być stosowana do badania nierównomierności odsysania $\mathrm{z}$ osadników multicyklonów o podobnej konstrukcji i nie tylko o prostopadłościennej komorze osadnika pyłu, ale i o konstrukcji kołowej.

Zapewnienie równomierności odsysania z pojedynczych cyklonów jest kolejnym etapem doskonalenia organizacji systemu odsysania pyłu z osadnika multicyklonu.

Praca naukowa finansowana ze środków na naukę w latach 2007-2009 jako projekt badawczy N504-O/0010/32.

\section{Bibliography/Literatura}

[1] Cenrtisep Air Cleaner: Materiały informacyjne firmy PALL Corporation, USA 2004.

[2] Baczewski K., Hebda M.: Filtracja płynów eksploatacyjnych, MCNEMT, Radom 1991/92.

[3] Dzierżanowski P., Miller Z.: Poszukiwania konstrukcyjnych sposobów podwyższania skuteczności bezwładnościowego odpylacza płaskiego, Biuletyn WAT, XL, 9 (469), 1991.

[4] Dzierżanowski P.: Bezwładnościowy odpylacz modułowy, Biuletyn WAT, XXXV, 2 (402), 1986.

[5] Dziubak T.: Analiza procesu filtracji powietrza wlotowego do silników pojazdów specjalnych, Rozprawa habilitacyjna, WAT, Warszawa 2008.

Mr. Tadeusz Dziubak, DSc., DEng, - Professor at the Faculty of Mechanics Military University of Technology, Warsaw, Poland.

Dr hab. inż. Tadeusz Dziubak-profesor nadzwyczajny na Wydziale Mechanicznym Wojskowej Akademii Technicznej w Warszawie.

e-mail: tdziubak@wat.edu.pl
[6] Dziubak T.: Model osadnika pyłu multicyklonu filtru powietrza silnika pojazdu terenowego eksploatowanego w warunkach dużego zapylenia powietrza, Zagadnienia Eksploatacji Maszyn PAN, z. 2(130), 2002.

[7] Dziubak T.: Problemy odsysania pyłu z multicyklonu filtru powietrza silnika pojazdu mechanicznego eksploatowanego w warunkach dużego zapylenia powietrza, Zagadnienia Eksploatacji Maszyn PAN, z. 1(125), 2001.

[8] Greenfield R.R.: The Use of Cyclones for Control of Solids Emission from Fluidised Bed Boilers, Filtration \& Separation, Vol. 22, No 1, 1986.

[9] Kim H. T., Zhu Y., Hinds W. C., Lee K.W.: Experimental Study of Small Virtual Cyclones as Particle Concentrators, Journal of Aerosol Science, Vol. 33, No 5, 2002.

[10] Krapke P.: Die Entwicklung des LEOPARD - 2. Soldat und Technik, No. 9, 1980.

[11] Mann+Hummel Air Cleaners.: www.mann-hummel.com.

[12] Рузаев И.Г., Стрыковский Ф.Р.: Исследование комбинированной системы очистки воздуха двигателей. Автомобильная промышленность, No. 8, 1979.

[13] Sage P.W., Wright M.A.: The Use of Bleeds to Enhance Cyclone Performance, Filtration \& Separation, Vol. 23, No. 1, 1986. 